\title{
Migration Behaviour Index - A Measure to Quantify the Migration Behaviour of Rural Youth
}

\author{
M. Anamica* and T.N. Sujeetha
}

Department of Agricultural Extension and Rural Sociology, TNAU, India

*Corresponding author

\author{
A B S T R A C T
}

\section{Keywords}

Migration of rural youth, Migration Behaviour Index.

\section{Article Info}

Accepted:

24 September 2017

Available Online:

10 November 2017
Exodus of youth from rural areas to urban areas has become an inevitable phenomenon in our country. The rural youth population of India is slowly deserting their origin and swarming towards the urban areas. The exodus of rural youth means fewer small-scale farmers, today and tomorrow. It is a global food security issue too. Having an insight into the rationale behind the exodus behavior of rural youth is hence crucial. Considering this point of view, a study was conducted among 160 migrant rural youths with agricultural background. The Migration Behaviour of rural youth has been studied by developing an appropriate measurement methodology that quantifies their migration behaviour. The Migration Behaviour Index was developed and the composite Migration Behaviour Index worked out was 0.70 . The Migration Behaviour Index value of fully migrated (0.75) was found to be higher than that of partially migrated ones $(0.66)$. While in quantifying indicator wise migration behavior, the index values of migration intention and migration network were found to be higher for the partially migrated rural youth than the fully migrated ones. The remaining index values of other indicators were higher for the fully migrated rural youth when compared to their counterparts.

\section{Introduction}

The rapid growth and diversification of developmental activities in India have resulted in much needed expansion of employment opportunities, but at the same time have triggered rural to urban migration (Web source: DARE, 2012). This trend has inadvertently resulted in shift of farm youth to non-farm sectors. Rising disenchantment with the profession has pushed them out of agriculture while opportunities in other sectors of the booming economy have pulled them out of agriculture (Sharma and Bhaduri, 2005). The study on migration of rural youth is crucial and imperative since it poses threat to India's food security.
Migration studies have emerged as an important focus of sociological and demographical studies in recent years, perhaps because of the increasing policy salience of internal and international population movements (De Jong, 2000).

Hammar et al., (1997) conveyed that there are numerous theories to explain migration (both at the state and national levels and at the individual and household levels), but a persistent gap is the relative lack of behavioural studies. Fischer et al., (1997) suggested another field open for further investigation of the dynamics of migration 
decision-making. Considering the issue of rural youth exodus and the above suggestions of various authors, the migration behaviour of rural youth has been quantified by devising appropriate measurement methodology and has been organized under the following sub sections.

Migration Behaviour Index

Indicator wise migration behaviour

\section{Research Methodology}

\section{Selection of study area and respondents}

The research was carried out in Coimbatore and Tirupur districts of Tamil Nadu by adopting an ex post facto research design during 2012-13.

The factors namely, the population decadal growth and the considerable area under agriculture ideally supported the selection of study area.

Coimbatore district has 12 blocks and Tirupur district has 13 blocks respectively. Two blocks have been selected from each district and a total of four blocks were selected based on key information from the officials of the State Department of Agriculture, area under agriculture and scope of studying the issue of rural youth migration.

Two revenue villages from each blocks were selected purposively based on the information provided by the State Department officials. From each revenue village, 10 fully migrated rural youth and 10 partially migrated rural youth with agricultural background were selected based on key informant method.

A total sample of 160 rural youth in the proportion of 80 fully migrated rural youth and 80 partially migrated rural youth were interviewed in accordance with the objective.

\section{Construction of Migration Behaviour Index}

\section{Identification and scrutiny indicators}

Identification of indicators of migration behaviour of rural youth was carried out through detailed analysis of literature. Further scrutiny was done by discussion with extension experts from the Department of Agricultural Extension and Rural Sociology of TNAU and Department of Extension Education of Gandhigram Rural University. Based on the preliminary discussion fourteen migration behaviour indicators were selected.

\section{Relevancy rating of the indicators}

The final inventory of indicators was subjected to expert opinions. The experts or judges were from the cadres of teaching faculty in Extension discipline of TNAU and Gandhigram Rural University. The experts were requested to specify whether each of the identified indicators were relevant and suitable for inclusion in Migration Behaviour Index.

Their responses were obtained on a three point continuum viz., 'Most Relevant', 'Relevant' and 'Less Relevant' frequencies with scoring pattern as 2, 1 and 0 respectively. The responses received from the judges were analysed and the Relevancy Weightage (RW) of ith indicator (RWi) was worked out by using the following formula.

Relevancy weightage for each indicator (RW) $=($ Most Relevant $* 2)+($ Relevant $* 1)+($ Not Relevant* 0) / Maximum Possible Score

Considering relevancy weightage, the indicators were screened for their relevancy. Accordingly, indicators having relevancy weightage of more than 0.74 were considered for inclusion in migration behaviour index. 
Using this procedure, fourteen components were selected under Migration Behaviour Index.

Of the selected indicators, seven indicators like nature of migration, nature of work, distance of work, migration decision making, migration network, family migration norm and remigration intention were the quantitative indicators/direct indicators. And the remaining seven indicators like aspiration, creativity, occupational mobility, migration intention, degree of social embeddedness, parental and peer influences and remittances were the qualitative/perceived indicators.

Followed by identification of major indicators of group dynamics, sub indicators were identified for each of the major indicator.

\section{Selection of sub-indicators}

Under each major indicator, sub-indicators were identified based on perusal of literature and discussion with experts. Followed by this, further discussion was held with the Advisory Committee members and other experts to finalize the sub-indicators. Based on the discussion, different sub-indicators were identified for the fourteen major migration behaviour indicators.

\section{Procedure for Migration Behaviour Index development}

The finalised schedule with fourteen major and their respective sub indicators were administered to the respondents. In case of the quantitative indicators the respondents were asked to put forth their choice from the sub indicators. The scores for the respective sub indicators were provided based on measurement and the scoring procedure already developed for the study. Ramasubramanian (2003) and Anamica (2010) have also used a part of these indicators. In case of the qualitative indicators the respondents were asked to give their responses based on a three point continuum scale viz., Agree (A), Undecided (UD) and Disagree (D) for which the scores given were 3, 2 and 1 respectively. Sub indicators were sequenced as per their weightage under major indicators.

\section{Quantification of indicators}

To evolve a composite Migration Behaviour Index and to derive meaningful conclusions, separate index was developed for each indicator. The procedure has been followed by Senthilkumar (2009) with necessary modification to apt for the study. The details of quantification of each indicator are furnished below in Table $2 \mathrm{a}$ and $2 \mathrm{~b}$.

\section{Migration Behaviour Index (MBI)}

Migration behaviour index was arrived by adding the score of each indicator viz., aspiration, creativity, occupational mobility, migration intention, nature of migration, nature of work in the migrated destination, distance of work place, degree of social embeddedness, parental and peer influence, migration decision making, migration network, family migration norm, remittances and remigration intention. The migration behaviour index was calculated by adopting the following formula.

$$
\begin{gathered}
\left(I_{1 x}+I_{2 x}+I_{3 x}+\ldots \ldots \ldots \ldots . . . I_{14 x}\right) \\
\left(I_{1 y}+I_{2 y}+I_{3 y}+\ldots \ldots \ldots \ldots . . . I_{14 y}\right)
\end{gathered}
$$

Where,

MBI - Migration behaviour index

$\mathrm{I}_{1 \mathrm{x}}$ - Total score obtained for $1^{\text {st }}$ indicator $\mathrm{I}_{14 \mathrm{x}}$ - Total score obtained for $14^{\text {th }}$ indicator 
$I_{1 y}$ - Total maximum possible score for $1^{\text {st }}$ indicator

$\mathrm{I}_{14 \mathrm{y}}$ - Total maximum possible score for $14^{\text {th }}$ indicator

Based on calculated composite migration behaviour index, the respondents were classified into three categories viz., low, moderate and high. Mean scores have been worked out for each indicators. Thus MBI was arrived as the average of composite fourteen major components.

\section{Results and Discussion}

\section{Migration Behaviour Index (MBI)}

In this study, migration behaviour has been operationalised as the mobility of a rural youth from his home place (source) to another place (destination) due to the influence of psychological, safety, security, and esteem needs. The Migration Behaviour Index has included 14 major indicators viz., aspiration, creativity, occupational mobility, migration intention, nature of migration, nature of work in the migrated destination, distance of work place, degree of social embeddedness, parental and peer influence, migration decision making, migration network, family migration norm, remittances and remigration intention.

Each major indicator was identified with sub indicators. Both major and sub indicators have been identified to work out Migration Behaviour Index (MBI). Besides, indices have been also worked out for each indicator. The MBI was administered to analyse the migration behaviour of the rural youth by combining sub indicators of all major indicators into a composite index. The responses of the respondents appropriate for fabricating MBI were carefully collected and presented in Table 3.
From the above table, it could be concluded that the indicator wise indexes for the 14 components were aspiration (0.84), creativity (0.70), occupational mobility (0.77), migration intention ( 0.82$)$, nature of migration (0.75), nature of work in the migrated destination (0.50), distance of work place (0.74), degree of social embeddedness (0.67), parental and peer influence (0.71), migration decision making (0.60), migration network (0.63), family migration norm (0.73), remittances (0.89) and remigration intention (0.52). Finally the composite Migration Behaviour Index worked out was 0.70.

It is quite evident from Table 3 that the migration behaviour index value of fully migrated (0.75) was found to be higher than that of partially migrated ones (0.66). It is also interesting to note that the index values of migration intention and migration network were found to be higher for the partially migrated rural youth than the fully migrated ones. The remaining index values of other indicators were higher for the fully migrated rural youth when compared to their counterparts.

The indicator wise findings and discussions of the Migration Behaviour Index are presented in the following segment.

\section{Indicator wise Migration Behaviour}

The fourteen major indicators included in the migration behaviour index were catergorised into direct indicators and perceived indicators. Each major and sub indicators were already subjected to standardization procedure. After the standardization process, responses were obtained. In case of the direct indicators, the respondents were asked to put forth their choice from the sub indicators. The scores for the respective sub indicators were provided based on measurement and the scoring procedure developed for the study. In case of 
the perceived indicators the responses have been obtained on a three point continuum viz., agree, undecided and disagree for which the scores given were 3, 2 and 1 respectively. Mean scores were computed for each of the sub indicators and average mean scores were arrived for the main indicators. The results are furnished in Table 4 for discussion.

\section{Nature of migration}

Nature of migration is the temporary or the permanent movement of rural youth from their native destination to another destination in response to their career prospects. From the above table it could be observed that the average mean score of nature of migration for the fully migrated rural youth (3.00) was higher than that of partially migrated ones (1.55). The reason behind it would be that the partially migrated rural youth were either temporary migrants or circular migrants who returned to their place of origin after a time to get involved in agriculture on part-time or seasonal basis. In contrast, the fully migrated rural youth were permanent migrants who exhibited no involvement in agriculture.

\section{Nature of work in the migrated destination}

Nature of work in the migrated destination is the kind or class of work the migrant rural youth has chosen in the migration destination. It is evident from the table that both the categories of rural youth were found to secure similar average mean score (1.00). All of them were found to take up non-agricultural jobs in the migrated destinations. They were observed to have taken up jobs like software programming, accounting, business, construction works, carpentry, centering, tailoring, mechanical and electrical works, supervising in industrial premises, tailoring, driving, cooking, labour in textile industries etc. The higher wages what they earn with the same physical strain implied comparatively to agriculture would have also induced them to choose non-agricultural jobs. They also preferred the comfortable atmosphere provided by industries, shops and other business premises rather than working under scorching sun in the agricultural fields.

\section{Distance of work place}

Distance of work place is the distance between the rural youth's residence and the migrated destination or the work place. The findings from the table reveal that the average mean score for distance of work place of the fully migrated rural youth (3.42) was higher than the partially migrated rural youth (2.57). The fully migrated rural youth were reported to have migrated to far away industrialized hubs like Chennai, Kancheepuram, Perambalur, Hosur, Bangalore, Vishakapattinam etc., since they have permanently moved out of agriculture. In contrast, the partially migrated rural youth were found to work in places that were quite near their villages, since it would facilitate them to periodically return back to take part in agriculture and the most desirable destinations being the industrially concentrated Coimbatore, Tirupur and Erode districts. Some of the temporary migrants were also found to work in faraway destinations, as the distance of work place is not a constraint in this era of highly developed road connectivity and cheap transport facilities.

\section{Migration decision making}

Migration decision making is the degree to which the rural youth and their kith and kin have participated in the decision to migrate. The average mean score for migration decision making of fully migrant rural youth (2.12) was slightly higher than the partially migrant rural youth (1.96). The rationale behind it would be that the fully migrated 
rural youth possessed more prior migration experience when compared to their counterparts. This would probably enhance their magnitude of independent decision making. Consultation with family members followed by friends and neighbours was the other commonly observed pattern of decision making prevailing in both the categories of rural youth since they would act as the information providers regarding prospective places to migrate, the job availabilities and stay place.

\section{Migration Network}

Migration network is a set of interpersonal ties that connect movers, former movers, and non-movers in places of origin and destination through social ties. It was quite interesting to note from the table that the average mean score value of partially migrated rural youth for migration network was higher (2.32) than their counterparts (1.52). The seasonal participation of partially migrated rural youth in agriculture would make them to break off their jobs temporarily. This would make the partially migrated to frame a strong niche of social network in order to take help in the form of information about new employment opportunities and areas to reside in unfamiliar places. In case of fully migrated rural youth, agents served as their network since human resources were recruited in bulk numbers for jobs in corporates, textile mills and showrooms, processing industries.

Table.1 List of selected migration behaviour indicators with their relevancy weightage

\begin{tabular}{|l|l|c|}
\hline S. No. & \multicolumn{1}{|c|}{ Indicators } & Relative Weightage Score \\
\hline 1. & Aspiration & 0.86 \\
\hline 2. & Creativity & 0.76 \\
\hline 3. & Occupational mobility & 0.94 \\
\hline 4. & Migration intention & 0.82 \\
\hline 5. & Nature of migration & 0.76 \\
\hline 6. & *Nature of work in the migrated destination & 0.54 \\
\hline 7. & *Distance of work place & 0.58 \\
\hline 8. & Degree of social embeddedness & 0.78 \\
\hline 9. & Parental and peer influence & 0.92 \\
\hline 10. & Migration decision making & 0.78 \\
\hline 11. & Migration network & 0.84 \\
\hline 12. & Family migration norm & 0.78 \\
\hline 13. & Remittances & 0.74 \\
\hline 14. & Remigration intention & 0.84 \\
\hline
\end{tabular}

*Included in the index based on perusal of previous research studies 
Table.2a Quantification of Direct Indicators

\begin{tabular}{|c|c|c|c|c|c|c|}
\hline \multirow[t]{2}{*}{ S.No } & \multirow{2}{*}{$\begin{array}{l}\text { Quantitative } \\
\text { Indicator }\end{array}$} & \multirow[t]{2}{*}{ Operationalisation } & \multicolumn{2}{|l|}{ Scoring Procedure } & \multirow[t]{2}{*}{ Formula } & \multirow{2}{*}{ Abbreviation } \\
\hline & & & Category & Score & & \\
\hline 1. & $\begin{array}{l}\text { Nature of } \\
\text { Migration }\end{array}$ & $\begin{array}{l}\text { The movement of the migrant from } \\
\text { one place to another and kind of } \\
\text { settlement either temporarily or } \\
\text { permanently in the migrated } \\
\text { destination }\end{array}$ & $\begin{array}{l}\text { Temporary Migration } \\
\text { Circular Migration } \\
\text { Permanent Migration }\end{array}$ & $\begin{array}{l}1 \\
2 \\
3\end{array}$ & $\begin{array}{l}\text { NMI=SSNM xi } \\
\text { / TSNM yi }\end{array}$ & $\begin{array}{l}\text { NMI= Nature of Migration Index } \\
\text { SSNM xi = Score secured by an individual } \\
\text { on NM domain } \\
\text { TSNM yi = Total possible score for an } \\
\text { individual on NM Domain }\end{array}$ \\
\hline 2. & $\begin{array}{l}\text { Nature of } \\
\text { Work }\end{array}$ & $\begin{array}{l}\text { The kind or class of work the migrant } \\
\text { has chosen in his migration destination }\end{array}$ & $\begin{array}{l}\text { Agricultural } \\
\text { Non Agricultural }\end{array}$ & $\begin{array}{l}2 \\
1\end{array}$ & $\begin{array}{l}\text { NWI=SSNW xi / } \\
\text { TSNW yi }\end{array}$ & $\begin{array}{l}\text { NWI = Nature of Work Index } \\
\text { SSNW xi = Score secured by an individual } \\
\text { on Nature of work domain } \\
\text { TSNW yi = Total possible score for an } \\
\text { individual on Nature of work domain }\end{array}$ \\
\hline 3. & $\begin{array}{l}\text { Distance of } \\
\text { Migration }\end{array}$ & $\begin{array}{l}\text { The distance between the rural youth's } \\
\text { residence and the migrated destination } \\
\text { or the work place }\end{array}$ & $\begin{array}{l}\text { Less than } 25 \mathrm{kms} \\
25-50 \mathrm{kms} \\
50-100 \mathrm{kms} \\
\text { More than } 100 \mathrm{kms}\end{array}$ & $\begin{array}{l}1 \\
2 \\
3 \\
4\end{array}$ & $\begin{array}{l}\text { DMI=SSDM xi / } \\
\text { TSDMyi }\end{array}$ & $\begin{array}{l}\text { DMI = Distance of Migration Index } \\
\text { SSDM xi = Score secured by an individual } \\
\text { on DM domain } \\
\text { TSDM yi = Total possible score for an } \\
\text { individual on DM domain }\end{array}$ \\
\hline 4. & $\begin{array}{l}\text { Migration } \\
\text { Decision } \\
\text { making }\end{array}$ & $\begin{array}{l}\text { The degree to which a rural youth and } \\
\text { his kin \& kith have participated in the } \\
\text { decision to migrate }\end{array}$ & $\begin{array}{l}\text { By self without consulting others. } \\
\text { Consultation with family members. } \\
\text { Consultation with others. }\end{array}$ & $\begin{array}{l}3 \\
2 \\
1\end{array}$ & $\begin{array}{l}\text { MDI=SSMD xi / } \\
\text { TSMD yi }\end{array}$ & $\begin{array}{l}\text { MDI = Migration Decision making Index } \\
\text { SSMD xi = Score secured by an individual } \\
\text { on MD domain } \\
\text { TSMD yi = Total possible score for an } \\
\text { individual on MD domain }\end{array}$ \\
\hline 5. & $\begin{array}{l}\text { Migration } \\
\text { Network }\end{array}$ & $\begin{array}{l}\text { The information providers on which } \\
\text { place to migrate, what job to pursue, } \\
\text { stay place etc and the presence of kin } \\
\text { and kith in the place the migrated rural } \\
\text { youth has moved or decided to move }\end{array}$ & $\begin{array}{l}\text { Family members or relatives } \\
\text { Friends or neighbours } \\
\text { Agencies }\end{array}$ & $\begin{array}{l}3 \\
2 \\
1\end{array}$ & $\begin{array}{l}\text { MNI=SSMN xi / } \\
\text { TSMN yi }\end{array}$ & $\begin{array}{l}\text { MNI = Migration Network Index } \\
\text { SSMN xi = Score secured by an individual } \\
\text { on migration network domain } \\
\text { TSMN yi = Total possible score for an } \\
\text { individual on migration network domain }\end{array}$ \\
\hline 6. & $\begin{array}{l}\text { Family } \\
\text { Migration } \\
\text { Norm }\end{array}$ & $\begin{array}{l}\text { The perception of family member's } \\
\text { towards migration of the rural youth }\end{array}$ & $\begin{array}{l}\text { Encourage to migrate } \\
\text { No idea } \\
\text { Do not encourage to migrate }\end{array}$ & $\begin{array}{l}3 \\
2 \\
1\end{array}$ & $\begin{array}{c}\text { FNI }=\text { SSFN xi / } \\
\text { TSFN yi }\end{array}$ & $\begin{array}{l}\text { FNI = Family migration Norm Index } \\
\text { SSFN xi = Score secured by an individual } \\
\text { on family migration norm domain } \\
\text { TSFN yi = Total possible score for an } \\
\text { individual on FN domain. }\end{array}$ \\
\hline 7. & $\begin{array}{l}\text { Remigration } \\
\text { Intention }\end{array}$ & $\begin{array}{l}\text { The thought about moving back or } \\
\text { returning back to the home location as } \\
\text { perceived and symbolically revealed } \\
\text { by the migrated rural youth }\end{array}$ & $\begin{array}{l}\text { Intend to return within a year } \\
\text { Intend to return within five years } \\
\text { Intend to return within } 5-10 \text { years } \\
\text { Intend to return after }<10 \text { years } \\
\text { No intention to return back }\end{array}$ & $\begin{array}{l}1 \\
2 \\
3 \\
4 \\
5\end{array}$ & $\begin{array}{l}\text { RII=SSRI xi / } \\
\text { TSRI yi }\end{array}$ & $\begin{array}{l}\text { RII = Remigration Intention Index } \\
\text { SSRI xi = Score secured by an individual on } \\
\text { Remigration Intention domain } \\
\text { TSRI yi = Total possible score for an } \\
\text { individual on RI domain }\end{array}$ \\
\hline
\end{tabular}


Table.2b Quantification of Perceived Indicators

\begin{tabular}{|c|c|c|c|c|}
\hline S.No & $\begin{array}{l}\text { Qualitative } \\
\text { Indicator }\end{array}$ & Operationalisation & Formula & Abbreviation \\
\hline 8. & Aspiration & $\begin{array}{l}\text { The rural youth's desired future states of being, } \\
\text { such as occupational attainments, level of living } \\
\text { and social status. }\end{array}$ & ASI=SSA xi / TSA yi & $\begin{array}{l}\text { ASI }=\text { Aspiration index } \\
\text { SSA xi = Score secured by an individual on aspiration domain } \\
\text { TSA yi = Total possible score for an individual on aspiration domain }\end{array}$ \\
\hline 9. & Creativity & $\begin{array}{l}\text { The rural youth's ability to appraise and sense } \\
\text { problems along with openness to divergent and } \\
\text { innovative thinking. }\end{array}$ & CRI $=S S C$ xi / TSC yi & $\begin{array}{l}\text { CRI = Creativity index } \\
\text { SSC xi = Score secured by an individual on creativity domain } \\
\text { TSC yi = Total possible score for an individual on creativity domain }\end{array}$ \\
\hline 10. & $\begin{array}{l}\text { Occupational } \\
\text { Mobility index }\end{array}$ & $\begin{array}{l}\text { The openness of rural youth to opportunities, } \\
\text { taking the risks of moving out and experimenting } \\
\text { with newer jobs and unfamiliar surroundings }\end{array}$ & $\begin{array}{l}\text { OMI=SSOM xi / } \\
\text { TSOM yi }\end{array}$ & $\begin{array}{l}\text { OMI = Occupational Mobility index } \\
\text { SSOM xi = Score secured by an individual on occupational mobility } \\
\text { domain } \\
\text { TSOM yi = Total possible score for an individual on occupational } \\
\text { mobility domain }\end{array}$ \\
\hline 11. & $\begin{array}{l}\text { Migration } \\
\text { Intention }\end{array}$ & $\begin{array}{l}\text { The rural youth's thought about moving out to } \\
\text { another destination in the past, present and future } \\
\text { to seek out his occupational aspirations }\end{array}$ & MII=SSMI xi /TSMI yi & $\begin{array}{l}\text { MII = Migration Intention Index } \\
\text { SSMI xi = Score secured by an individual on migration intention domain } \\
\text { TSMI yi = Total possible score for an individual on migration intention } \\
\text { domain }\end{array}$ \\
\hline 12. & $\begin{array}{l}\text { Social } \\
\text { Embeddedness }\end{array}$ & $\begin{array}{l}\text { The extent of entrenchment or attachment of the } \\
\text { rural youth towards his home, community and } \\
\text { migrated destination }\end{array}$ & SEI=SSSE xi /TSSE yi & $\begin{array}{l}\text { SEI = Degree of Social Embeddedness Index } \\
\text { SSSE xi = Score secured by an individual on degree of social } \\
\text { embeddedness domain } \\
\text { TSSE yi = Total possible score for an individual on degree of social } \\
\text { embeddedness domain }\end{array}$ \\
\hline 13. & $\begin{array}{l}\text { Parental and } \\
\text { peer Influence }\end{array}$ & $\begin{array}{l}\text { The role of parents and friends in persuading or } \\
\text { inducing the rural youth to migrate }\end{array}$ & PII=SSPI xi / TSPI yi & $\begin{array}{l}\text { PII = Parental and peer Influence Index } \\
\text { SSPI xi = Score secured by an individual on parental and peer influence } \\
\text { domain } \\
\text { TSPI yi = Total possible score for an individual on parental and peer } \\
\text { influence domain. }\end{array}$ \\
\hline 14. & Remittances & $\begin{array}{l}\text { The thought about moving back or returning back } \\
\text { to the home location as perceived and } \\
\text { symbolically revealed by the migrated rural youth }\end{array}$ & $\begin{array}{l}\text { REI=SSRE xi / } \\
\text { TSRE yi }\end{array}$ & $\begin{array}{l}\text { REI = Remittances Index } \\
\text { SSRE xi = Score secured by an individual on remittances domain } \\
\text { TSRE yi = Total possible score for an individual on remittances domain }\end{array}$ \\
\hline
\end{tabular}


Table.3 Indicator wise Migration Behaviour Index score

\begin{tabular}{|l|l|c|c|c|}
\hline \multirow{2}{*}{ S. No. } & \multirow{2}{*}{ Migration Behaviour Indicators } & \multicolumn{2}{|c|}{ Index Score } \\
\cline { 3 - 4 } & & $\begin{array}{c}\text { Fully Migrated } \\
(\mathbf{n = 8 0})\end{array}$ & $\begin{array}{c}\text { Partially Migrated } \\
(\mathbf{n = 8 0})\end{array}$ & $\begin{array}{c}\text { Total } \\
(\mathbf{n = 1 6 0})\end{array}$ \\
\hline $\mathbf{1 .}$ & Aspiration & 0.86 & 0.82 & 0.84 \\
\hline $\mathbf{2 .}$ & Creativity & 0.72 & 0.68 & 0.70 \\
\hline $\mathbf{3 .}$ & Occupational mobility & 0.85 & 0.69 & 0.77 \\
\hline $\mathbf{4 .}$ & Migration intention & 0.82 & 0.83 & 0.82 \\
\hline $\mathbf{5 .}$ & Nature of migration & 1.00 & 0.51 & 0.75 \\
\hline $\mathbf{6 .}$ & Nature of work & 0.50 & 0.50 & 0.50 \\
\hline $\mathbf{7 .}$ & Distance of work place & 0.85 & 0.64 & 0.74 \\
\hline $\mathbf{8 .}$ & Degree of social embeddedness & 0.76 & 0.59 & 0.67 \\
\hline $\mathbf{9 .}$ & Parental and peer influence & 0.74 & 0.69 & 0.71 \\
\hline $\mathbf{1 0 .}$ & Migration decision making & 0.70 & 0.50 & 0.60 \\
\hline $\mathbf{1 1 .}$ & Migration network & 0.50 & 0.77 & 0.63 \\
\hline $\mathbf{1 2 .}$ & Family migration norm & 0.75 & 0.71 & 0.73 \\
\hline $\mathbf{1 3 .}$ & Remittances & 0.90 & 0.88 & 0.89 \\
\hline $\mathbf{1 4}$. & Remigration intention & 0.58 & 0.47 & 0.52 \\
\hline & Composite MBI score & $\mathbf{0 . 7 5}$ & $\mathbf{0 . 6 6}$ & $\mathbf{0 . 7 0}$ \\
\hline
\end{tabular}

Table.4 Mean scores on the Migration Behaviour of rural youth

\begin{tabular}{|c|l|c|c|}
\hline S. No. & \multicolumn{1}{|c|}{ Migration Behaviour Indicators } & \multicolumn{2}{c|}{ Mean Score } \\
\hline & Direct indicators & FM (n=80) & PM (n=80) \\
\hline I & Nature of migration & $\mathbf{3 . 0 0 / 3 . 0 0}$ & $\mathbf{1 . 5 5 / 3 . 0 0}$ \\
\hline & Temporary & - & $36(45.00 \%)$ \\
\hline & Circular & - & $44(65.00 \%)$ \\
\hline & Permanent & $80(100 \%)$ & - \\
\hline II & Nature of work in the migrated destination & $\mathbf{1 . 0 0 / 2 . 0 0}$ & $\mathbf{1 . 0 0 / 2 . 0 0}$ \\
\hline & Agricultural & - & - \\
\hline & Non-agricultural & $80(100 \%)$ & $80(100 \%)$ \\
\hline III & Distance of work place & $\mathbf{3 . 4 2 / 4 . 0 0}$ & $\mathbf{2 . 5 7 / 4 . 0 0}$ \\
\hline & Less than 25 kms & - & $8(10.00 \%)$ \\
\hline & 25-50 kms & $10(12.50 \%)$ & $34(42.50 \%)$ \\
\hline & 50-100 kms & $26(32.50 \%)$ & $22(27.50 \%)$ \\
\hline & More than 100 kms & $44(55.00 \%)$ & $16(20.00 \%)$ \\
\hline IV & Migration decision making & $\mathbf{2 . 1 2 / 3 . 0 0}$ & $\mathbf{1 . 9 6 / 3 . 0 0}$ \\
\hline & By self & $28(35.00 \%)$ & $25(31.25 \%)$ \\
\hline & Family members & $34(42.50 \%)$ & $27(33.75 \%)$ \\
\hline & Others & $18(22.50 \%)$ & $28(35.00 \%)$ \\
\hline V & Migration Network & $\mathbf{1 . 5 2 / 3 . 0 0}$ & $\mathbf{2 . 3 2 / 3 . 0 0}$ \\
\hline & Family members or relatives & $6(7.70 \%)$ & $30(37.50 \%)$ \\
\hline & Friends or Neighbours & $30(37.50 \%)$ & $46(57.50 \%)$ \\
\hline & Agencies & $44(55.00 \%)$ & $4(5.00 \%)$ \\
\hline VI & Family migration norm & $\mathbf{2 . 2 5 / 3 . 0 0}$ & $\mathbf{2 . 1 5 / 3 . 0 0}$ \\
\hline & Encourage to migrate & $40(50.00 \%)$ & $32(40.00 \%)$ \\
\hline & No idea & $20(25.00 \%)$ & $28(35.00 \%)$ \\
\hline & Do not encourage to migrate & $20(25.00 \%)$ & $20(25.00 \%)$ \\
\hline VII & Remigration intention & $\mathbf{2 . 9 0 / 5 . 0 0}$ & $\mathbf{2 . 3 5 / 5 . 0 0}$ \\
\hline & Intend to return within a year & $14(17.50 \%)$ & $14(17.50 \%)$ \\
\hline & Intend to return within five years & $24(30.00 \%)$ & $38(47.50 \%)$ \\
\hline & Intend to return within 5-10 years & $14(17.50 \%)$ & $14(17.50 \%)$ \\
\hline & & &
\end{tabular}




\begin{tabular}{|c|c|c|c|}
\hline & Intend to return after 10 years & $12(15.00 \%)$ & $14(17.50 \%)$ \\
\hline & No intention to return & $16(20.00 \%)$ & - \\
\hline & Perception indicators & & \\
\hline VIII & Aspiration & $2.60 / 3.00$ & $2.46 / 3.00$ \\
\hline 1. & To earn more money within next five years. & 3.00 & 2.95 \\
\hline 2. & To increase material possession within next five years. & 2.97 & 2.85 \\
\hline 3. & To alter house/construct new house within next five years. & 2.05 & 1.97 \\
\hline 4. & To purchase lands within next five years. & 2.30 & 1.87 \\
\hline 5. & To reach a better social status within next five years. & 2.70 & 2.67 \\
\hline IX & Creativity & 2.08/3.00 & 2.05/3.00 \\
\hline 1. & Desire to go beyond convention. & 2.30 & 1.87 \\
\hline 2. & Fascinating new tasks and areas. & 2.35 & 2.25 \\
\hline 3. & Restructuring problems and recognize ideas. & 1.92 & 1.97 \\
\hline 4. & Working on several ideas simultaneously. & 1.92 & 2.10 \\
\hline 5. & Elaborating and expanding ideas. & 1.92 & 2.07 \\
\hline $\mathbf{X}$ & Occupational mobility & 2.56/3.00 & 2.07/3.00 \\
\hline 1. & Fondness to travel to unknown destinations in search of job. & 2.60 & 1.95 \\
\hline 2. & No hesitation to pick jobs in unfamiliar areas. & 2.47 & 1.92 \\
\hline 3. & No vacillation to mingle with people in unfamiliar surroundings. & 2.77 & 2.15 \\
\hline 4. & Easiness to get accommodated to the new culture and customs. & 2.85 & 2.07 \\
\hline 5. & Readiness to grasp job oriented skills that are new. & 2.12 & 2.30 \\
\hline XI & Migration intention & 2.47/3.00 & $2.50 / 3.00$ \\
\hline 1. & Intention to migrate in the past. & 3.00 & 2.95 \\
\hline 2. & Intention to migrate currently. & 2.50 & 2.67 \\
\hline 3. & Intention to migrate in future. & 1.75 & 2.05 \\
\hline XII & Degree of social embeddedness & 2.28/3.00 & $1.78 / 3.00$ \\
\hline 1. & Preference to stay in the migrated place than home place. & 1.95 & 1.57 \\
\hline 2. & Feeling safe and secure staying in the migrated destination. & 2.12 & 1.60 \\
\hline 3. & $\begin{array}{l}\text { Feeling comfortable surrounded by people belonging to other } \\
\text { community. }\end{array}$ & 2.45 & 1.72 \\
\hline 4. & Preference to work with people belonging to other community. & 2.45 & 1.87 \\
\hline 5. & Leaving family in native when moving to unfamiliar places. & 2.45 & 2.15 \\
\hline XIII & Parental and peer influences & 2.24/3.00 & 2.09/3.00 \\
\hline 1. & Commune looks down upon farming. & 2.00 & 2.65 \\
\hline 2. & Parents want to move out of agriculture. & 1.90 & 1.92 \\
\hline 3. & Migration following friends in urban areas. & 2.62 & 1.87 \\
\hline 4. & Family wants to make more money like friends. & 2.05 & 1.87 \\
\hline 5. & Families of prospective brides do not prefer farming youth. & 2.65 & 2.15 \\
\hline XIV & Remittances from migration & 2.72/3.00 & $2.65 / 3.00$ \\
\hline 1. & Has increased income status. & 2.82 & 2.90 \\
\hline 2. & Has given economic independence. & 2.85 & 2.90 \\
\hline 3. & Has increased the ability to support family financially. & 2.95 & 2.90 \\
\hline 4. & Has encouraged creating assets. & 2.42 & 2.42 \\
\hline 5. & A security for future life. & 2.55 & 2.15 \\
\hline
\end{tabular}

\section{Family migration norm}

Family migration norm is the perception of family members towards migration of the rural youth. From the table it could be interpreted that the average mean score for the family migration norm of fully migrated rural youth (2.25) was found to be slightly higher than that of the partially migrated ones (2.15). During the field survey the researcher was able to observe that a good number of farm families of rural youth possessed an optimistic aptitude towards migration and also encouraged the process of migration. The 
reason behind it being that the income from migration would act as a source of revenue during non-agricultural seasons and would be helpful in further investment in agriculture.

\section{Remigration intention}

Remigration intention is the thought about moving back or returning back to the home location as perceived and symbolically revealed by the migrated rural youth. It is apparent from the table that the average mean score for remigration intention of fully migrated rural youth (2.90) was more than that of the partially migrated rural youth (2.35). Though the fully migrated rural youth were permanent migrants, majority possessed the intention to return back to their native. The affiliation towards their home community and the idea of settling in their home place after earning sufficient money would have influenced their remigration intention. Some of them were not interested to return back to their native. Their educational qualification, higher expectancy of income and comfort in the migrated destination would have influenced their remigration intention inversely. On contrary, all the temporarily migrated youth possessed the intention to remigrate to their villages. Their periodical participation in agriculture, affiliation towards their family and home community and the idea of carrying out farming on full scale after their parents, would be the possible reasons

\section{Aspiration}

Aspiration is defined as an individual's desire to obtain a status object or goal such as a specific occupational, economical and social status. A perusal of data in the table indicates that the average mean score for the aspirations of the fully migrated rural youth (2.60) was high than that of partially migrated ones (2.46). Though both the category of rural youth have the aspirations of attaining a stable economic and social status, the material and property possession aspirations of the fully migrated rural youth were seen on the higher end. Moreover, the researcher was able to observe an intricate relationship between the educational status and the aspirations of the rural youth. It is quite common that when the enhanced educational status of the rural youth increases, their aspirations would also increase. On contrary, it was interesting to note that the educational attainment of the rural youth did not deter both the categories from aspiring for a better economic and social status. Further, whatever would be the economic background of the family, both the categories exhibited aspirations to step ahead.

\section{Creativity}

Creativity of rural youth is usually characterized by a high degree of originality and innovation, divergent thinking and risk taking. The results pertinent to creativity shows that the average mean score for fully migrated rural youth (2.08) and partially migrated youth (2.05) were more or less similar. The fully migrated rural youth were found to possess the desire to go beyond convention i.e. permanently migrating instead of involving in agriculture. They were open to new tasks and also fascinated traveling to new areas in search of better career opportunities. On the other hand, their counterparts were not engrossed with the idea of moving beyond convention and were not comfortable with moving to unfamiliar areas in search of new jobs. This would be the stimulus behind their periodical visits to their native and engage in part-time or seasonal involvement in farming. The risks involved in practicing agriculture would have made them to work on several ideas simultaneously. They concurrently involved in farming and managed the risks in agriculture by temporarily migrating to cities and towns to take up jobs to sustain their livelihoods. 


\section{Occupational mobility}

Occupational mobility is the openness of rural youth to opportunities, taking the risks of moving out and experimenting with newer jobs and diverse surroundings. From the table it is clear that the average mean score for occupational mobility of fully migrated rural youth (2.56) was higher than that of the partially migrated rural youth (2.07). The fully migrated rural youth were open to pick new jobs in unknown destination. They were also found to easily mingle with people and get accommodated to the new culture and customs of the new places. Thus the quality of experimentation and higher affiliation expectancy from the migrated destination higher would have influenced their occupational mobility in a positive way. On the other hand, the stronger affiliation towards family and home community, family migration norm and the affirmative attitude towards agriculture could have limited the occupational mobility of the partially migrated ones.

\section{Migration intention}

Migration intention is the rural youth's thought and plan about moving out to another destination in the past, present and future. Table 4 shows that the average mean score of partially migrated rural youth (2.50) was slightly more than the fully migrated rural youth (2.47). The intention to migrate in the future was found to prevail more in the partially migrated rural youth when compared to their counterparts. Despite the fact that the partially migranted involved in agriculture on part-time or seasonal basis, they were reported to be keen on diversifying their occupational patterns. Expanding the occupational domain would generate additional employment and income besides agriculture. The income from farming would compromise their family income during non- agricultural seasons and manage the risks that may arise out from farming. Conversely majority of the fully migrated rural youth expressed their opinion to return back to their villages in near future after earning sufficiently, in spite of their strong migration intention in the past and present.

\section{Degree of social embeddedness}

Degree of social embeddedness is the extent to which a rural youth is attached or entrenched with his family, home community and degree to which a particular collectivity forms a group. Lower the degree of social embeddedness with the home community, higher would be the migration behaviour. The results presented in the table indicates that the average mean score for the degree of social embeddedness was more for fully migrated youth (2.28) when compared to their counterparts (1.78). The fully migrated youth readily got acclimatized with their new environment and unknown people around them. This would be the rationale behind their mean score to be higher on the degree of social embeddedness. On the other hand the partially migrant rural youth preferred to be within the niche of people belonging to their home community even after migration. They migrated to places where strong migration network ties were available. Thus high degree of social embeddedness with their home community would be the reason behind their periodical involvement in farming.

\section{Parental and peer influences}

The role of parents and friends in persuading and inducing the rural youth to migrate is inevitable. Thus, the parental and peer influence would possibly achieve migration tendency of rural youth. When comparing the average mean scores of both the categories, the fully migrated (2.24) were found to possess a high mean score than their 
counterparts (2.09). Most of the fully migrated rural youth were found to have followed their friends who have already migrated. Since the families of these rural youth wanted them to make more money as their friends do. Also majority of them felt that families of prospective bride do not prefer rural youth in farming. All these reasons would have stimulated the rural youth to opt for a permanent migration. On the other hand, the parents of the partially migrated were found to encourage them to move out of agriculture since the income from migration would pacify their family income during off seasons. Moreover the commune around the rural youth considered farming to be the least profitable venture. This would be the foremost reason for both the categories of rural youth to get migrated in different strengths.

\section{Remittances from migration}

Remittances are the positive outcome of migration achieved through the migrant's income sent from the destination of employment to the family in the native. It was indeed found to have a positive impact on the migration prospects of rural youths' economical and psychological status. The findings from the table further shows the average mean scores for the remittances from migration of fully migrated and partially migrated rural youth to be 2.72 and 2.65 respectively. From the responses obtained, it was clear that remittances from migration have improved their financial and social status. Thus remittances from migration have positively persuaded the migration behaviour of the rural youth by stimulating their migration intention to move currently or in future. On the contrary, it also negatively influenced the remigration intention of rural youth, as the rural youth would still thrive hard to sustain and enhance the economic and social status achieved through migration.
Investing in young people living in rural areas is the key to enhancing agricultural productivity and food security in addition to boosting rural economies and reducing ruralto- urban migration. Young farmers and producers often have greater capacity for innovation and entrepreneurship than older adults. Due to their limited access to assets (in particular land), markets, finance and education and skills training, rural youth are often unemployed or work informally. If young people living in rural areas do not find enough incentives, profitable economic opportunities and attractive environments in which to live and work, they will continue to migrate to cities. This trend would affect the global food production. The crucial issue of "Who will then feed the global population that is projected to reach 9.2 billion people by 2050 ?" also arises here. The genuine solution is to invest in 'the rural youth of today, the farmers of tomorrow'. This study on quantification of migration behaviour of rural youth will support the policy makers, planners and development professionals have an insight into the rationale behind the exodus of rural youth, the challenges they face and the unfulfilled requirements of agrarian rural youth. It would also enlighten them to formulate special agricultural policies focusing on agrarian rural youth and thereby develop strategies to empower them, attract them and retain them in agriculture and thus ensuring a promising future for them in India.

\section{Acknowledgement}

I extend my profound thanks to the 'Jawarharlal Nehru Memorial Fund Scholarship For Doctoral Studies' for financially aiding me to carry out this extensive research on Migration of Rural Youth - An Analysis. I also express my sincere thanks to the chairman of my advisory committee for his constant support and guidance. 


\section{References}

Anamica, M. 2010. Migration Behaviour of Dryland Farmers - An Expost Facto Study. Unpub. M.Sc. (Ag.) Thesis, TNAU, Coimbatore.

De Jong. 2000. Expectations, Gender, and Norms in Migration Decision-Making. Population Studies, 54: 307-319.

Fischer, P. A., M. Reiner and S. Thomas. 1997. Should I Stay or Should I Go? In Thomas Hammar et al., (eds.), International Migration, Immobility and Development. Oxford: Berg Press, 4990.

Hammar, T., B. Grete, T. Kristof and F. Thomas. 1997. International Migration,
Immobility and Development. Oxford: Berg Press.

http://dare.nic.in/node/

Ramasubramanian, M. 2003. Developing Strategies for Sustainable Dry Farming. Unpub. Ph.D. Thesis, TNAU, Coimbatore.

Senthilkumar, R. 2009. Risk Management Behavioural Pattern of Paddy Farmers An Empirical Study. Unpub. Ph.D. Thesis, TNAU, Coimbatore.

Sharma, A. and A. Bhaduri. 2007. The Tipping Point in Indian Agriculture. Available at: www.nrlp.org/Docs/DReports/phase_01 /07\%20Indian\%20agricultureMigration- \%20sharma\%20et\%20al.pdf

\section{How to cite this article:}

Anamica, M. and Sujeetha, T.N. 2017. Migration Behaviour Index - A Measure to Quantify the Migration Behaviour of Rural Youth. Int.J.Curr.Microbiol.App.Sci. 6(11): 3044-3057. doi: https://doi.org/10.20546/ijcmas.2017.611.357 